\title{
ESTIMASI KEBUTUHAN IMPOR DAGING SAPI UNTUK KONSUMSI RUMAH TANGGA DI INDONESIA MENGGUNAKAN REGRESI ROBUST ${ }^{*}$
}

\author{
Ratnasari ${ }^{1}$, Ray Sastri ${ }^{2 \ddagger}$ \\ 1Badan Pusat Statistik Kabupaten Bangka Selatan, email: ratnasari@bps.go.id \\ 2Politeknik Statistika STIS, email: raysastri@stis.ac.id \\ ¥corresponding author \\ Indonesian Journal of Statistics and Its Applications (eISSN:2599-0802) \\ Vol 2 No 2 (2018), 93-100
}

Copyright (C) 2018 Ratnasari and Ray Sastri. This is an open-access article distributed under the Creative Commons Attribution License, which permits unrestricted use, distribution, and reproduction in any medium, provided the original work is properly cited.

\begin{abstract}
Beef import to Indonesia always gets pros and cons. The government argue that we need it to reduce the high price of beef due to the scarcity. On the other hand, Indonesia is an agrarian country with a lot of cattle farms. We should be able to meet the needs of beef from domestic production without import. The aim of this study is to get the best model for household consumption of beef at the district level, and use the model to estimate the import needs. This study uses data from Statistics Indonesia, both the raw data of National Sosio-economic Survey (SUSENAS) and beef production in district level. The methods of analysis is a robust regression model. The results is robust regression fit the data well. For households need, estimation of household consumption of beef is lower than domestic production. So that, Indonesia does not need to import beef for household need.
\end{abstract}

Keywords: beef consumption, import, robust regression, Susenas.

\section{Pendahuluan}

Permasalahan impor daging sapi ke Indonesia selalu mendapatkan pro dan kontra. Pemerintah berpendapat bahwa impor tersebut perlu dilakukan untuk menekan harga pasar di tengah kelangkaan daging sapi di pasaran. Sedangkan pihak kontra berpendapat bahwa Indonesia adalah negara agraris dengan peternakan sapi yang banyak seharusnya bisa memenuhi sendiri kebutuhan daging sapinya.

\footnotetext{
* Received Nov 2018; Accepted Nov 2018; Published online on Nov 2018
} 
Kebijakan pemerintah tentu saja harus berdasarkan pada data. Dilihat dari trennya pada Gambar 1, impor daging sapi Indonesia dari 1996 hingga 2014 mengalami peningkatan. Impor daging sapi mengalami kenaikan yang tajam pada tahun 2004 dan tahun 2014. Kenaikan impor tersebut disebabkan adanya pembebasan kuota impor oleh pemerintah. Selanjutnya, penurunan pada tahun 2015 disebabkan oleh adanya pemotongan kuota impor dari Australia oleh pemerintah dalam upaya pencapaian target swasembada daging sapi yaitu penyediaan sapi domestik 90 persen (Kementerian Perdagangan (2015), Kementerian Pertanian (2011 \& 2016)).

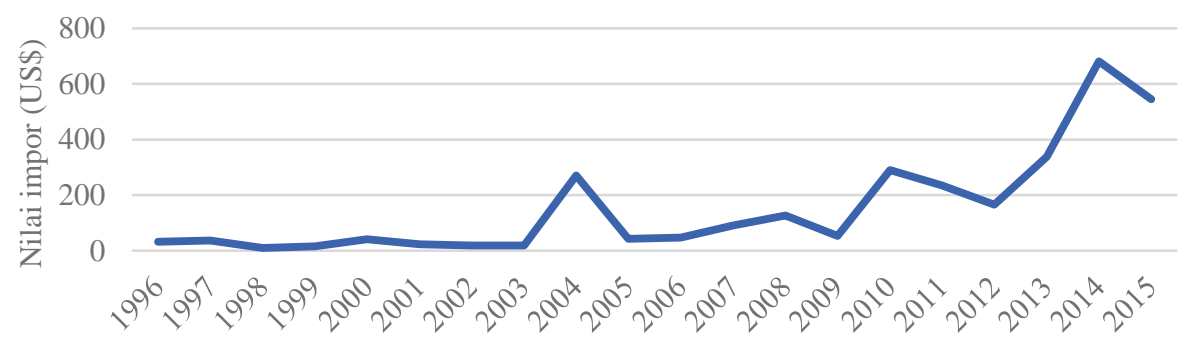

Sumber: BPS

Gambar 1: Perkembangan impor daging sapi di Indonesia tahun 1996-2015

Peningkatan impor daging sapi dalam rangka menekan harga perlu untuk dikaji lagi. Pengkajian ulang tersebut diperlukan karena harga daging sapi impor malah cenderung mengalami kenaikan yang dapat dilihat pada Gambar 2. Pada tahun 2016 harga daging sapi mencapai Rp 116.751 per kg, harga tersebut naik 11,91 persen dari harga tahun 2015 yang besarnya Rp 104.328 per kg (Sumber: BPS).

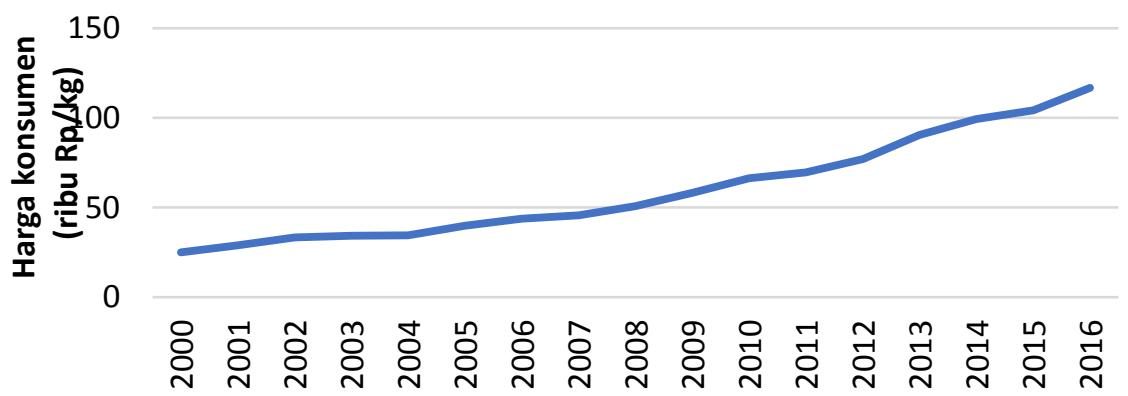

Sumber: BPS

Gambar 2: Harga Konsumen Daging Sapi di Indonesia Tahun 2000-2016

Kebutuhan impor dapat diketahui dari selisih permintaan dan persediaan daging sapi dalam negeri. Estimasi permintaan dapat didekati dari sisi konsumsi daging sapi di tingkat rumah tangga yang digabungkan menjadi estimasi permintaan daging sapi pada level kabupaten/kota. Hal ini berguna bagi 
pemerintah dalam memperkirakan kabupaten/kota mana yang mengalami defisit/surplus daging sapi sebagai bahan pertimbangan dalam penyusunan kebijakan dalam hal distribusi ke wilayah regional yang lebih kecil. Selain itu, konsumsi daging sapi dipengaruhi oleh banyak hal. Sehingga estimasinya dapat dilakukan dengan pemodelan menggunakan peubah penjelas karakteristik demografi dan ekonomi wilayah.

Perbedaan karakteristik antar kabupaten/kota dalam hal demografi dan ekonomi memungkinkan adanya perbedaan daya beli daging sapi di tingkat rumah tangga. Pada kota-kota yang perekonomiannya maju dengan daya beli tinggi, bisa jadi konsumsi daging sapinya berbeda jauh dengan kabupaten/kota yang lainnya. Adanya nilai-nilai tidak biasa (pencilan) ini menyebabkan perlunya perlakuan khusus dalam pemodelan statistik.

Tujuan dari penelitian ini adalah mendapatkan model untuk mengestimasi konsumsi daging sapi untuk keperluan rumah tangga pada level kabupaten/kota di Indonesia, serta mengestimasi jumlah impor daging sapi untuk keperluan rumah tangga Indonesia.

\section{Metodologi}

\subsection{Data}

Penelitian ini menggunakan data Survei Sosial Ekonomi Nasional (Susenas) tahun 2016 yang dilakukan oleh Badan Pusat Statistik (BPS). Dalam Susenas, data dikumpulkan pada tingkat rumah tangga. Untuk mendapatkan data pada tingkat kabupaten/kota, data rumah tangga digabungkan pada setiap kabupaten/kota. Unit analisis dari penelitian ini adalah 513 kabupaten/kota di seluruh Indonesia.Data pendukung analisis yaitu jumlah penduduk dan produksi daging sapi diambil dari Daerah Dalam Angka tahun 2016 yang dipublikasikan oleh BPS.

\subsection{Metode Penelitian}

Metode analisis yang digunakan adalah regresi berganda, dengan beberapa asumsi yang harus dipenuhi yaitu: error harus menyebar normal, bersifat homoskedastis, tidak ada autokorelasi antar error, dan tidak ada multikolinieritas di antara variable-variabel penjelas. Asumsi kenormalan diuji dengan uji Kolmogorov-Smirnov, homoskedastisitas diuji dengan uji Glejser, autokorelasi dijui dengan uji Durbin Watson, dan multikolinieritas ditentukan dengan melihat nilai VIF. Pemilihan model terbaik dilakukan dengan backward elimination, dan identifikasi pencilan dilakukan dengan menggunakan nilai standardized residual. Jika nilainya lebih dari |2| maka amatan tersebut termasuk sebagai pencilan.

Pengamatan berupa pencilan dapat menyebabkan permasalahan pada metode OLS. Sehingga disarankan menggunakan regresi robust untuk membatsi pengaruh pencilan pada nilai estimasi parameter (Andersen, 2008). Metode analisis yang digunakan dalam penelitian ini adalah dengan regresi robust. 
Regresi robust biasa digunakan untuk memodelkan data-data dengan permasalahan yang disebabkan oleh pencilan-pencilan.

Model regresi robust yang akan dibentuk adalah sebagai berikut:

$$
\begin{aligned}
\widehat{Y}_{\mathrm{i}}= & \widehat{\beta}_{0}+\widehat{\beta}_{1} X_{1 i}+\widehat{\beta}_{2} X_{2 i}+\widehat{\beta}_{3} X_{2 i}+\widehat{\beta}_{4} X_{4 i}+\widehat{\beta}_{5} X_{5 i}+\widehat{\beta}_{6} X_{6 i}+\widehat{\beta}_{7} X_{7 i}+\widehat{\beta}_{8} X_{8 i}+\widehat{\beta}_{9} X_{9 i} \\
& +\widehat{\beta}_{10} X_{10 i}+\widehat{\beta}_{11} X_{11 i}+\widehat{\beta}_{12} X_{12 i}+\widehat{\beta}_{13} X_{13 i}+\widehat{\beta}_{14} X_{14 i}
\end{aligned}
$$

Keterangan:

i : Indeks untuk daerah kabupaten/kota.

$Y$ : Konsumsi daging sapi per kapita per minggu (gram)

$X_{1}$ : Jumlah anggota rumah tangga

$X_{2}$ : Persentase penduduk laki-laki (persen)

$X_{3}$ : Rata-rata umur penduduk (tahun)

$X_{4}$ : Persentase KRT dengan pendidikan tertinggi SMA ke atas (persen)

$X_{5}$ : Persentase KRT dengan lapangan usaha di bidang pertanian (persen)

$X_{6}$ : Persentase KRT dengan status pekerjaan berusaha (persen)

$X_{7}$ : Rata-rata pendapatan per kapita per bulan (Rupiah)

$X_{8}:$ : Klasifikasi Kabupaten/Kota (Kabupaten=1, Kota=0)

$X_{9}$ : Nilai konsumsi ikan per kapita per minggu (Rupiah)

$X_{10}$ : Konsumsi daging ayam per kapita per minggu $(\mathrm{kg})$

$X_{11}$ : Konsumsi telur per kapita per minggu (butir)

$X_{12}$ : Nilai konsumsi sayuran per kapita per minggu (Rupiah)

$X_{13}$ : Konsumsi tahu dan tempe per kapita per minggu $(\mathrm{kg})$

$X_{14}$ : Nilai konsumsi makanan jadi per kapita per minggu (Rupiah)

Dimana parameter $\boldsymbol{\beta}$ akan diduga menggunakan metode pendugaan $\mathrm{M}$. Secara umum penduga parameter akan didapatkan dengan dengan cara meminimumkan fungsi berikut:

$$
\begin{gathered}
\hat{\beta}_{m}=\min \sum_{i=1}^{n} \rho\left(\frac{y_{i}-\sum_{j=0}^{k} x_{i j} \beta_{j}}{\hat{\sigma}}\right)=\min \sum_{i=1}^{n} \rho\left(\frac{e_{i}}{s}\right)=\min \sum_{i=1}^{n} \rho\left(\frac{e_{i}}{s}\right) \\
s=\frac{\text { median }\left|e_{i}-\operatorname{median}(e)\right|}{0,6745}=\frac{M A D}{0,6745}
\end{gathered}
$$

di mana s adalah skala pendugaan yang bersifat robust dan MAD adalah median absolute deviation. Nilai minimum dari fungsi (4) dilakukan dengan iteratively reweighted least squares (IRLS).

Ukuran kebaikan model yang digunakan dalam pemodelan regresi robust yaitu sebagai berikut :

$$
R_{w}^{2}=\left(\frac{\sum_{i=1}^{n} w_{i}\left(y_{i}-\bar{y}_{w}\right)\left(\hat{y}_{i}-\bar{y}_{w}\right)}{\sqrt{\sum_{i=1}^{n} w_{i}\left(y_{i}-\bar{y}_{w}\right)^{2} \sum_{i=1}^{n} w_{i}\left(\hat{y}_{i}-\overline{\hat{y}}_{w}\right)^{2}}}\right)^{2}
$$

di mana $\bar{y}_{w}=\left(\frac{1}{\sum w_{i}}\right) \sum w_{i} y_{i}, \overline{\hat{y}}_{w}=\left(\frac{1}{\sum w_{i}}\right) \sum w_{i} \hat{y}_{i}$, dan $w_{i}$ adalah penimbang robust. 


\section{Hasil dan Pembahasan}

Model regresi berganda terbaik didapatkan dengan $\mathrm{R}^{2}$ sebesar 0,477 . Nilai VIF menunjukkan tidak ada multikolinieritas, tetapi uji kenormalan menyimpulkan bahwa error tidak berdistribusi normal. Selain itu, asumsi homoskedastis dan non autokorelasi juga terlanggar. Untuk mengatasi pelanggaran asumsi dilakukan transformasi dan pemberian pembobot. Akan tetapi, transformasi tidak berhasil mengatasi ketidaknormalan, dan pemberian bobot tidak berhasil mengatasi heteroskedastisitas.

Pengecekan terhadap pencilan berdasarkan nilai standardized residual dari model regresi berganda yang terbentuk menyimpulkan bahwa terdapat 30 kabupaten/kota yang memiliki nilai lebih besar dari |2|, sehingga kabupaten/kota tersebut termasuk sebagai pencilan. Penghapusan pencilan mampu menghasilkan model regresi OLS yang lebih sesuai dengan $R^{2}=57,5$ persen dan standard error yang lebih kecil. Akan tetapi, penghapusan pencilan menyebabkan sebanyak 30 kabupaten/kota tidak masuk dalam analisis penelitian. Padahal bisa jadi 30 kabupaten/kota tersebut mengandung informasi penting. Oleh karena itu, dilakukan pemodelan menggunakan regresi robust.

Berdasarkan Tabel 2, terdapat perbedaan penduga parameter yang cukup signifikan antara model regresi berganda dengan pencilan dan tanpa pencilan. Sebaliknya, nilai penduga parameter untuk model regresi robust dengan pencilan dan tanpa pencilan menunjukkan hasil yang mirip/hampir sama. Hal ini menunjukkan bahwa model regresi OLS mudah dipengaruhi oleh adanya pencilan, sedangkan model robust bersifat kekar (robustness) terhadap adanya pencilan tersebut. Nilai penduga parameter model regresi robust mendekati penduga parameter model regresi OLS tanpa pencilan. Hampir semua nilai penduganya mirip, kecuali koefisien regresi untuk X2 dan X3.

Tabel 2. Perbandingan Nilai Penduga Parameter Metode OLS dan Robust

\begin{tabular}{ccccc}
\hline \multirow{2}{*}{ Variabel } & \multicolumn{2}{c}{$\begin{array}{c}\text { Koefisien Regresi dengan } \\
\text { OLS }\end{array}$} & \multicolumn{2}{c}{$\begin{array}{c}\text { Kofisien Regresi dengan } \\
\text { Penduga Robust }\end{array}$} \\
\cline { 2 - 5 } & $\begin{array}{c}\text { Dengan } \\
\text { Pencilan }\end{array}$ & $\begin{array}{c}\text { Tanpa } \\
\text { Pencilan }\end{array}$ & $\begin{array}{c}\text { Dengan } \\
\text { Pencilan }\end{array}$ & $\begin{array}{c}\text { Tanpa } \\
\text { Pencilan }\end{array}$ \\
\hline Intercept & $36,38338^{*}$ & $18,44612^{*}$ & $12,86502^{*}$ & 11,14008 \\
X2 & $-0,60356^{*}$ & $-0,27318^{*}$ & $-0,13611$ & $-0,10491$ \\
X3 & $-0,41951^{*}$ & $-0,30752^{*}$ & $-0,26478^{*}$ & $-0,2673^{*}$ \\
X6 & $0,05494^{*}$ & $0,0341^{*}$ & 0,01829 & 0,01913 \\
X7 & $0,00001^{*}$ & $0,00001^{*}$ & $0,00001^{*}$ & $0,00001^{*}$ \\
X8 & $-1,75223^{*}$ & $-1,74426^{*}$ & $-2,00817^{*}$ & $-2,05753^{*}$ \\
X9 & $-0,00033^{*}$ & $-0,00025^{*}$ & $-0,00018^{*}$ & $-0,00019^{*}$ \\
X11 & $1,36463^{*}$ & $1,15462^{*}$ & $1,19827^{*}$ & $1,04472^{*}$ \\
X12 & $-0,00015$ & $-0,00015$ & $-0,0001^{*}$ & $-0,00011^{*}$ \\
X13 & 7,88342 & 7,73706 & $7,31962^{*}$ & $7,63188^{*}$ \\
\hline
\end{tabular}


Tabel 3. Perbandingan Nilai Standard Error Metode OLS dan Robust

\begin{tabular}{cccc}
\hline Variabel & $\begin{array}{c}\text { Standard error } \\
\text { OLS }\end{array}$ & $\begin{array}{c}\text { Standard error OLS } \\
\text { tanpa pencilan }\end{array}$ & $\begin{array}{c}\text { Standard error } \\
\text { robust }\end{array}$ \\
\hline $\begin{array}{c}(1) \\
\text { (Constant) }\end{array}$ & 9,3918 & $(3)$ & $(4)$ \\
X2 & 0,1609 & 6,6094 & 6,7616 \\
X3 & 0,1105 & 0,1135 & 0,1158 \\
X6 & 0,0207 & 0,0778 & 0,0795 \\
X7 & 0,0000 & 0,0145 & 0,0149 \\
X8 & 0,7664 & 0,0000 & 0,0000 \\
X9 & 0,0001 & 0,5532 & 0,5518 \\
X11 & 0,4526 & 0,0000 & 0,0000 \\
X12 & 0,0001 & 0,3285 & 0,3258 \\
X13 & 2,5159 & 0,0000 & 0,0000 \\
\end{tabular}

Berdasarkan Tabel 3, nilai standard error model robust lebih kecil bila dibandingkan nilai standard error OLS dengan pencilan. Sedangkan bila dibandingkan dengan model OLS tanpa pencilan, nilai standard erromya hampir sama. Hal ini menunjukkan bahwa regresi robust lebih baik untuk digunakan dibandingkan metode OLS. Hasil estimasi regresi robust juga sama baiknya dengan metode OLS setelah dilakukan penghapusan pencilan. Sehingga regresi robust ini dapat mengatasi kelemahan OLS yang sangat peka terhadap adanya pencilan.

Hasil uji simultan menghasilkan bahwa model regresi robust sesuai untuk memodelkan data konsumsi daging sapi di Indonesia dengan $R_{w}^{2}=0,524$. Model regresi robust yang terbentuk adalah:

$$
\begin{gathered}
\hat{Y}_{i}=\begin{array}{c}
12,865-0,136 X_{2 i}-0,265 X_{3 i}+0,0183 X_{6 i}+0,0000074 X_{7 i}-2,008 X_{8 i} \\
(0,057)(0,239)(0,001)^{*}(0,220) \\
-0,00018 X_{9 i}+1,198 X_{11 i}-0,0000992 X_{12 i}+7,320 X_{13 i}
\end{array} \\
(0,000)^{*}(0,000)^{*}(0,027)^{*}(0,000)^{*}
\end{gathered}
$$

Keterangan: *signifikan pada tingkat signifikansi $5 \%$

Hasil dari uji parsial yang ditunjukkan dalam Persamaan (1) menyatakan bahwa rata-rata umur, pendapatan per kapita, klasifikasi kabupaten/kota, konsumsi ikan, telur, sayuran, dan tahu/tempe terbukti berpengaruh signifikan terhadap konsumsi daging sapi kabupaten/kota di Indonesia. Sedangkan variabel lainnya, yaitu persentase penduduk laki-laki dan status pekerjaan KRT tidak berpengaruh secara signifikan.

Model regresi robust yang terbentuk selanjutnya dapat digunakan untuk mengestimasi konsumsi daging sapi pada level kabupaten di Indonesia. Secara umum, kabupaten/kota yang konsumsi daging sapi per kapita per minggunya tinggi terletak di Indonesia bagian barat. Untuk kabupaten/kota di wilayah Indonesia timur, konsumsi daging sapi per kapitanya tidak setinggi wilayah Indonesia barat. Hasil estimasi dapat dilihat pada Gambar 3. 


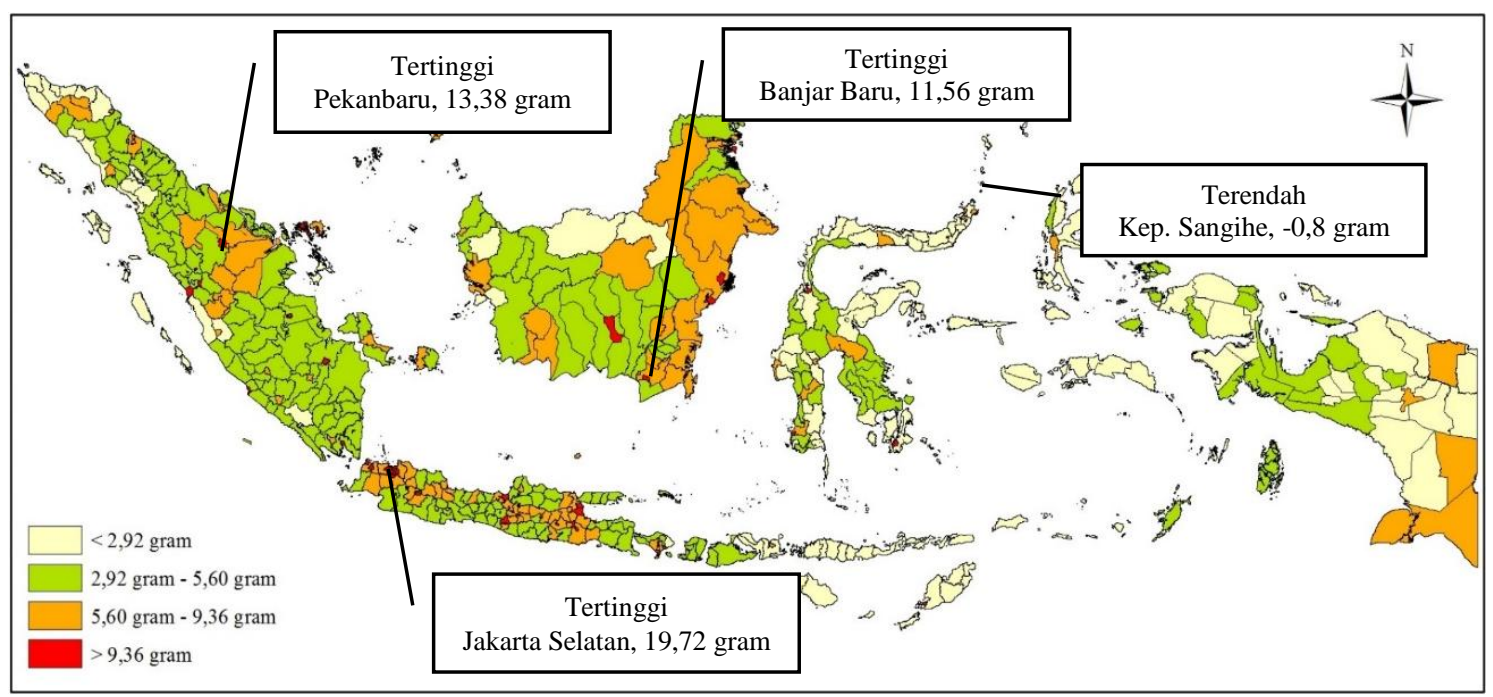

Gambar 3: Estimasi konsumsi daging per kapita per minggu di Indonesia tahun 2016

Untuk keperluan rumah tangga, selisih konsumsi dan produksi menunjukkan hasil positif, yang artinya untuk mencukupi permintaan rumah tangga di Indonesia sudah cukup dengan menggunakan sapi produksi dalam negeri. Sehingga Indonesia tidak perlu melakukan impor daging sapi.

Dari hasil estimasi konsumsinya, terdapat 39 kabupaten/kota yang produksi daging sapinya masih kurang dari konsumsi. Kabupaten/kota tersebut yang kemudian menjadi target impor. Jika dilihat dari batas wilayah administratifnya, sebagian besar kabupaten/kota yang mengalami kekurangan produksi daging sapi dikelilingi oleh kabupaten/kota yang mengalami surplus produksi. Sehingga kekurangan produksi daging sapi dari kabupaten/kota tersebut masih bisa dipenuhi dari daerah tetangga. Contohnya di provinsi Aceh, di mana kabupaten Simeulue dan Aceh Barat mengalami kekurangan produksi daging sapi tetapi masih bisa dipenuhi dengan daging sapi dari daerah sekelilingnya yang mengalami surplus produksi daging sapi, seperti Aceh Timur, Aceh Tengah, dan Aceh Besar. Hal tersebut juga terjadi di Jawa, Bali, Nusa Tenggara Timur, Kalimantan, Sulawesi, dan Maluku. Khusus untuk kabupaten/kota tertentu, misalnya yang berbentuk kepulauan biasanya tidak memproduksi daging sapi sendiri. Contohnya di Jakarta Pusat dan Kepulauan Seribu yang tidak ada produksi daging sapinya. Sehingga pemenuhan konsumsi daging sapi pada kedua kabupaten/kota tersebut dilakukan dengan memasok dari daerah lain.

Berbeda dengan kabupaten/kota lainnya, kabupaten/kota di provinsi Papua tidak dapat memenuhi kekurangan produksi daging sapinya dari daerah sekelilingnya. Hal ini dikarenakan banyaknya kabupaten/kota yang mengalami kekurangan daging sapi di provinsi Papua. Sebanyak 13 kabupaten/kota mengalami kekurangan produksi daging sapi dari 29 kabupaten/kota yang ada di Papua. 


\section{Simpulan}

Kesimpulan dari penelitian ini adalah (1) model regresi robust fit untuk memodelkan data konsumsi daging sapi sehingga dapat digunakan untuk mengestimasi konsumsi daging sapi di Indonesia. (2) Untuk keperluan rumah tangga, selisih konsumsi dan produksi menunjukkan hasil positif, yang artinya untuk mencukupi permintaan rumah tangga di Indonesia sudah cukup dengan menggunakan sapi produksi dalam negeri. Sehingga Indonesia tidak perlu melakukan impor daging sapi.

\section{Daftar Pustaka}

Andersen, R. (2008). Modern methods for robust regression (No. 152). Sage.

Kementerian Perdagangan. (2015). Kajian Efektivitas Kebijakan Impor Produk Pangan dalam Rangka Stabilisasi Harga. Jakarta: Badan Pengkajian dan Pengembangan Kebijakan Perdagangan Kementarian Perdagangan.

Kementerian Pertanian. (2011). Cuplikan Blue Print Program Swasembada Daging Sapi 2014, Analisis Kebijakan Pertanian, Vol. 9 (4), hlm. 391-404.

Kementerian Pertanian. (2016). Outlook Daging Sapi. Jakarta: Pusat Data dan Sistem Informasi Pertanian.

Montgomery, D. C., \& Peck, E. A. (1992). Introduction to Linear Regression Analysis. New York: A Wiley-Interscience Publication.

Sukirno, S. (2005). Teori Pengantar Mikroekonomi Edisi Ketiga. Jakarta: PT Raja Grafindo Persada. 